\title{
STUDY OF CLINICAL MANIFESTATIONS AND COMPLICATIONS OF HAEMOTOXIC SNAKE ENVENOMATION
}

Y. V. L. Narasimham ${ }^{1}$, B. Srinivasa Rao ${ }^{2}$

\section{HOW TO CITE THIS ARTICLE:}

Y. V. L. Narasimham, B. Srinivasa Rao. "Study of Clinical Manifestations and Complications of Haemotoxic Snake Envenomation". Journal of Evolution of Medical and Dental Sciences 2015; Vol. 4, Issue 57, July 16; Page: 9871-9876, DOI: $10.14260 /$ jemds/2015/1428

ABSTRACT: BACKGROUND AND OBJECTIVES: Snake bites are of major public health importance in many communities as causes of haemorrhage, other morbidity and mortality. ${ }^{1}$ Of the 3000 species of snakes, about 500 belong to the 3 families of venomous snakes, Atractaspididae, Elapidae and Viperidae. Estimated 15000-20000 people die each year from snake bite in India. ${ }^{2}$ In tropical countries snake bite is occupational disease of farmers, plantation workers and hunters. In India after snake bite clinical manifestations are pain, oedema, bleeding at bite site. ${ }^{3}$ The inpatient complaints are hypovolemic shock, bleeding diathesis, renal failure, sepsis. ${ }^{4,5}$ The only specific treatment is Anti Snake Venom (A. S. V). In India most cases of renal injuries are caused by Russell's viper and Saw scaled viper.6,7 METHODS: Patients with history of snake bite with or without bite marks, bleeding diathesis or with prolonged clotting time or both. And observed for oliguria and high coloured urine to see renal injury. Period to brought to hospital (Below 4 hours is ideal time) early or late, tourniquet application and level of consciousness, and did the simple bed side test is 20 minute blood clot test and prothrombin time, platelet count. RESULTS: Out of 50 cases 35 cases are males and 15 cases are females, so common in males. Common symptoms are nausea, vomits, pain, swelling and paresthesia. Common signs are bleeding from bleeding site, gum bleeding, epistaxis, haemetemesis, malena. CONCLUSION: It is found more common in males. Common symptoms nausea, vomit, pain, swelling. Common sign are bleeding at bite site, gum bleeding, epistaxis, haemetemesis, malena, decreased urine output, giddiness and vertigo.

KEYWORDS: Clinical examination, History, Physical examination, 20 minutes blood clot test and other laboratory investigation.

INTRODUCTION: Snake bite envenomation is a frequently encountered problem in tropical countries like India, especially in rural areas of south India. Most of the victims are agricultural workers. The only specific treatment for poison snake bite is anti-venom. ${ }^{8}$ Sero therapy must be initiated as early as possible to save life and to avert complications. ${ }^{9}$ The main object of the study is to highlight the evaluation of different clinical manifestations and complications.

The venom will contain $90 \%$ dry weight protein, composing enzymes, polypeptides, free amino acids $80-90 \%$, viperid and $25-70 \%$ elapid. Elapid venom consists enzymes, hydrolases, hyaluronidase, phospholipase $A_{2}$ is the most wide spread and extensively studied of all venom enzymes. ${ }^{10}$ Hyaluronidase promotes spread of venom through tissues. And hydrolases responsible for local change like oedema, blistering, bruising and necrosis. ${ }^{11,12}$

AIM OF THE STUDY: Study of clinical manifestation and complications of haemotoxic snake envenomation. 


\section{ORIGINAL ARTICLE}

\section{MATERIALS AND METHODS:}

\section{Inclusion Criteria:}

a) Patients with $\mathrm{H} / \mathrm{O}$ snake bite with oedema with bleeding diathesis or with prolonged clotting time or both.

b) Patients with altered sensorium, oliguria, jaundice.

c) Patients with 14 years and above age are taken for study.

\section{Exclusion Criteria:}

1. Patients with $\mathrm{H} / \mathrm{O}$ snake bite with any neurological manifestations such as ptosis, respiratory failure.

2. Patients without bite mark.

3. Patients age below 14 years.

Place and Period: King George Hospital, Visakhapatnam 1 year period from 2013 to 2014 were taken into study.

History and Examination: The patients referred for snake bite to outpatient department and casuality and were admitted. Ages groups 14 years and above are included, both males and females were included, people belonging to various socioeconomic classes were included. All patients were questioned for detailed history.

In addition to general symptoms specific symptoms oedema, bleeding diathesis, oliguria, level of sensorium, fang marks were carefully evaluated.

\section{Special Emphasis on the Following Points:}

1. Snake bite in relation time of bite and site of bite.

2. Whether tourniquet applied or not.

3. Any bleeding diathesis.

4. Urine output, colour of urine.

5. Examination of bite marks, blebs, blisters, sloughing, gangrene, necrosis.

6. Vital signs, pulse, blood pressure, respiratory rate, temperature. Look for anemia, jaundice, pedal oedema, peri orbital oedema are stigmata of renal failure.

Laboratory: Urine analysis, albumin, sugar, RBC, bile salts, bile pigments. Blood for TC, DC, ESR, HB\%, bleeding time, clotting time, peripheral smear for fragmented RBC, platelet count, blood urea, serum creatinine, prothrombin time $(\uparrow)$, fibrinogen degradation products (FDP) ( $\uparrow$ ), aspartate amino tranferage $(\uparrow)$.

ECG: ST-T changes signs, bradycardia, myocardial ischemia,. X ray chest to R/O pulmonary oedema, pulmanary infarcts, secondary broncho pneumonia,. U/S abdomen, CT brain to R/O intra cerebral bleed and subarchnoid haemorrhage.

Bedside Test: 20 minute whole blood clotting test. Incoagulable blood is a cardinal sign of systemic envenoming by most of the vipiridae. 
OBSERVATION: Study conducted 50 patients admitted to medical wards of King George Hospital during the period of 2013 to 2014. Both male and female cases were taken. Males were 35 cases, females were 15 cases. Age group 14 years and above were taken. Detailed analysis of symptoms pain $50 \%$, swelling $25 \%$, nausea and vomitings $20 \%$, pain abdomen $5 \%$. Detailed examination signs revealed that bleeding gums $44 \%$, decreased urine output $40 \%$, bleeding from multiple sites $26 \%$, giddiness $15 \%$.

ECG changes revealed ST-T changes 5\% and observed the complications are in Table 4.

\section{CONCLUSION: The Present Study Indicates:}

1. Out of 50 cases 35 cases were males, 15 cases were females. So it is common in males.

2. The time interval below 4 hours after bite and tourniquet application had decreased complications.

3. The common clinical findings pain, oedema, bleeding diathesis.

4. The common complications are bleeding diathesis, hypotension and shock, renal failure, gangrene and sepsis.

5. The 20 minute whole blood clot test positive (No clot formation) in all cases.

6. Renal parameters and hepatic enzymes are raised.

SUMMARY: It is found that snake bite more common among males. The onset of complications in haemotoxic envenomation, and time onset depends upon the factors like the severity of envenomation the time onset of sero therapy.

\section{BIBLIOGRAPHY:}

1. Gordon C. Cook. Man Sons tropical diseases 2003, 21st edition, London, ELBS, 32; 582 - 593.

2. Upadhyaya AC at al snake bite presenting as acute mi, ischemic CVA, ARF and Dic, JAPI 2000 Nov, 48(11); 1109-10.

3. Hutton Ra \& Warrell DA. Action of snake venom components: The haemostatic system blood Rev 1993 Sep, 7(3); 176-189.

4. Nicholas A. Boon. Davidsons Principle and practice of medicine 20th edition 2006, London, Churchill living stone, 9; 221-222.

5. Anantha Narayan, Textbokk of micro biology $7^{\text {th }}$ edition, 2005, Orient longman, Chennai. Ch 11; 81-82.

6. Y. Thewjtcharen. Ventricular Tachycardia Rare manifestations of russels viper bite. J. Med Assoc. Thai 20005 Dec, 88(12); 1931-33.

7. KS Chugh. Snake bite induced ARF in India. Kidney int. 1989 Mar. 35(3); $891-907$.

8. Swaroop S and Grab B; Snake bite Mortality in the world. Bull word Health organ 1954; 10(1); 35-76.

9. Anthony S. Fauci. Harrisons Internal Medicine, $17^{\text {th }}$ edition, 2008, London, Mc Grahill Chapter 391; 2741-43.

10. K. D. Tripati. Essesntials of medical pharmacology $6^{\text {th }}$ edition 2008, New Delhi, JP Brothers; 887-88.

11. FE. Russel. Snake Venom poisoning in USA. Feb 1980, Vol 31; 247 - 59.

12. T. Devaraj. Bleeding Manifestations in Snake bite, South east asian J Trop med public health 1979; 10(2); 255-57. 


\section{ORIGINAL ARTICLE}

\begin{tabular}{|c|c|c|c|}
\hline \multirow{2}{*}{ Age (Years) } & \multicolumn{2}{|c|}{ Envenonation } & \multirow{2}{*}{ Total } \\
\cline { 2 - 3 } & Male & Female & \\
\hline $14-30$ & 12 & 8 & 20 \\
\hline $31-40$ & 8 & 4 & 12 \\
\hline $41-50$ & 6 & 2 & 8 \\
\hline $51-60$ & 5 & 1 & 6 \\
\hline$>60$ & 3 & 1 & 4 \\
\hline
\end{tabular}

\begin{tabular}{|c|c|c|}
\hline Site of Bite & Number of Cases & Percentage (\%) \\
\hline Lower Limb & 38 & 76 \\
\hline Upper Limb & 8 & 16 \\
\hline Trunk & 4 & 8 \\
\hline \multicolumn{2}{|c|}{ Table 2: Site of Bite } \\
\hline
\end{tabular}

\begin{tabular}{|c|c|c|}
\hline CT & Number of Cases & Percentage (\%) \\
\hline Prolonged & 46 & 92 \\
\hline Normal & 4 & 8 \\
\hline Total & $\mathbf{5 0}$ & $\mathbf{1 0 0}$ \\
\hline \multicolumn{3}{|c|}{ Table 3: Clotting Time } \\
\hline
\end{tabular}

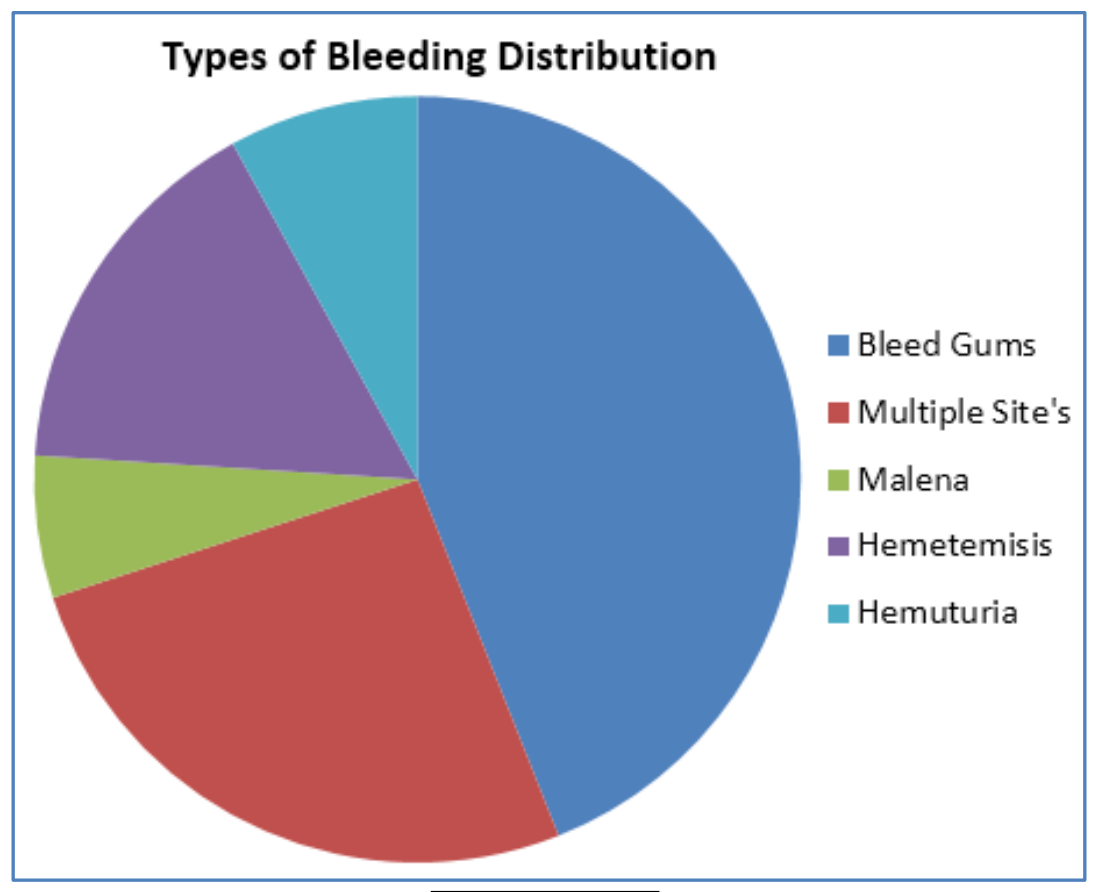

Graph 1 
ORIGINAL ARTICLE

\begin{tabular}{|c|c|c|c|}
\hline Sl. No. & Complications & Number of Cases/50 & Percentage (\%) \\
\hline 1 & Bleeding Gums & 44 & 88 \\
\hline 2 & Bleeding Multiple Sites & 26 & 52 \\
\hline 3 & Renal Failure & 22 & 44 \\
\hline 4 & Hypotension \& Shock & 10 & 20 \\
\hline 5 & Compartment Syndrome & 10 & 20 \\
\hline 6 & Gangrene & 4 & 8 \\
\hline 7 & Jaundice & 4 & 8 \\
\hline 8 & Sepsis & 2 & 4 \\
\hline
\end{tabular}

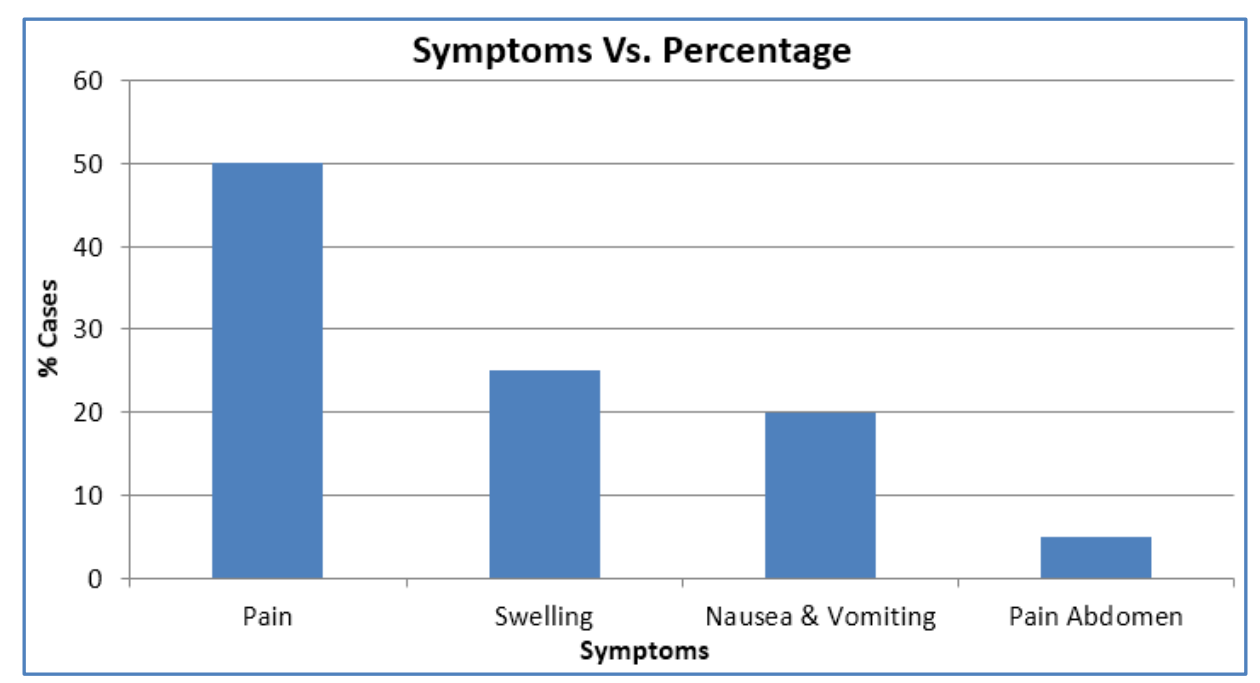

\section{Graph 2}

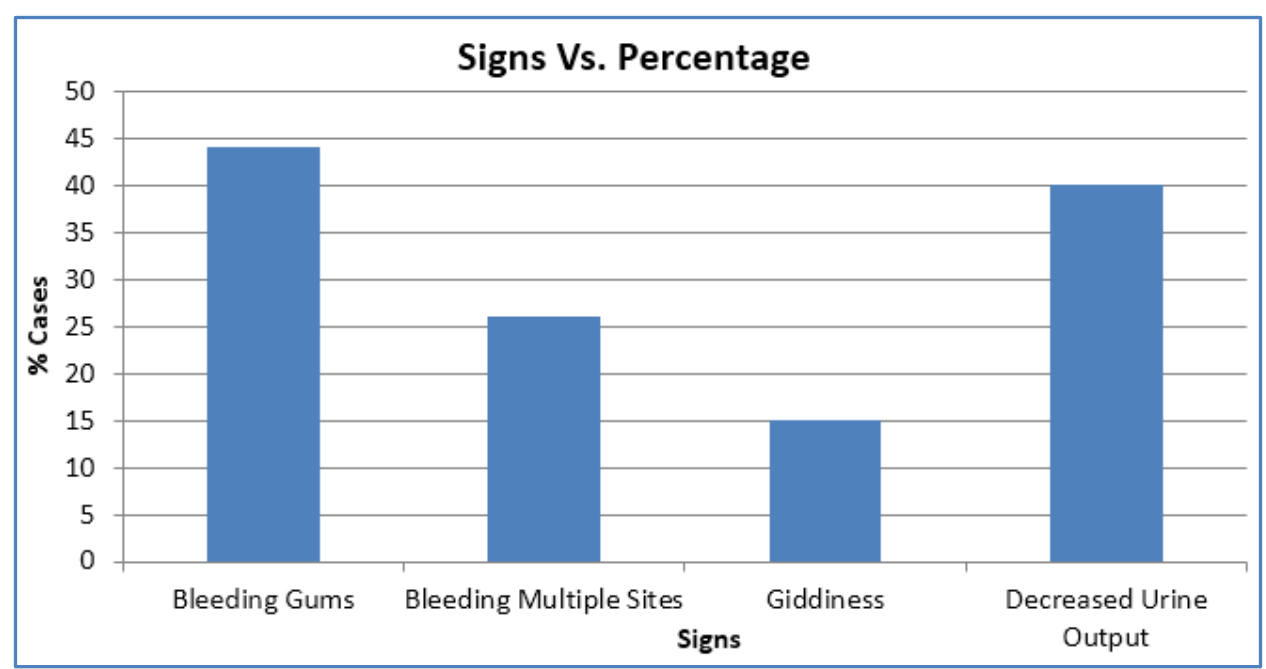

Graph 3 


\section{ORIGINAL ARTICLE}

\section{AUTHORS:}

1. Y. V. L. Narasimham

2. B. Srinivasa Rao

\section{PARTICULARS OF CONTRIBUTORS:}

1. Associate Professor, Department of General Medicine, Andhra Medical College, Visakhapatnam.

2. Assistant Professor, Department of General Medicine, Andhra Medical College, Visakhapatnam.

\section{FINANCIAL OR OTHER} COMPETING INTERESTS: None

NAME ADDRESS EMAIL ID OF THE CORRESPONDING AUTHOR:

Dr. Y. V. L. Narasimham, Door No. 10-106, Sri Sai Raghavendra Residency, FF3, Visalakshi Nagar,

Visakhapatnam-43, Andhra Pradesh.

E-mail: yatirajula_narasimham@yahoo.com

Date of Submission: 19/06/2015. Date of Peer Review: 20/06/2015. Date of Acceptance: 09/07/2015. Date of Publishing: 14/07/2015. 